\title{
PENYULUHAN MANAJEMEN SISTEM PERTANDINGAN OLAHRAGA UNTUK PENGEMBAN KEGIATAN KARANG TARUNA DI DESA GIRI MUKTI KECAMATAN SAGULING KAB. BANDUNG BARAT
}

\author{
${ }^{1 *}$ Akhmad Sobarna, ${ }^{2}$ Rony Mohamad Rizal, ${ }^{3}$ Sumbara Hambali, \\ ${ }^{4}$ Henry Asmara, ${ }^{5}$ Denok Sunarsi \\ ${ }^{1234}$ Sekolah Tinggi Keguruan dan Ilmu Pendidikan Pasundan \\ ${ }^{5}$ Universitas Pamulang \\ Email : $\underline{1 \text { akhmadsobarna9@gmail.com }}$
}

Manuskrip: Nov -2020; Ditinjau: Des -2020; Diterima: Des -2020;

Online: Jan-2021; Diterbitkan: Jan-2021

\begin{abstract}
ABSTRAK
Tujuan dari kegiatan pengabdian kepada masyarakat ini adalah untuk memenuhi kewajiban dosen untuk melakukan tridharma perguruan tinggi. Untuk itu sudah menjadi kewajiban bagi dosen berbagi pengetahuan dan wawasan melalui penyuluhan pengembangan manajemen system pertandingan olahraga agar senantiasa berupaya mencapai tujuan organisasi sistem pertandingan olahraga dengan efektif dan efisien. Dan juga bertujuan Karang Taruna Desa Girimukti Kecamatan Saguling Kabupaten Bandung Barat dapat menjalankan fungsi dan perannya secara optimal sehingga mendatangkan manfaat bagi Karang Taruna Desa Girimukti Kecamatan Saguling. Pengembangan juga dimaksudkan untuk meningkatkan kualitas sumber daya manusia Karang Taruna dalam melaksanakan tugasnya sehingga lebih positif dalam berkontribusi tenaga dan pikiran untuk memajukan keolahragaan di Desa Girimukti Kecamatan Saguling Kabupaten Bandung Barat.
\end{abstract}

\section{Kata Kunci : Manajemen Sistem Pertandingan Olahraga.}

\section{PENDAHULUAN}

Manajemen sitem pertandingan olahraga merupakan seni dan ilmu mengelola dalam kegiatan olahraga baik itu olahraga dalam rangka kegiatan multi event ataupun kegiatan kompetisi olahraga di daerah daerah seperti pedesaan yang dimana kalau di Desa peran suatu organisasi karang taruna yang dapat mengatur proses kegiatan olahraga yang dimana karang taruna perlu ditingkatkan kemampuan sumber daya manusia tentang system organisasi pertandingan dan sumber daya yang lain secara efektif dan efisien untuk mencapai tujuan., Atau secara rinci merupakan proses mulai dari perencanaan, pengorganisasian, pelaksanaan, pengendalian, sampai evaluasi hasil yang dilakukan secara efektif dan efisien dalam mencapai tujuan system organisasi pertandingan olahraga dapat dimengerti oleh pemuda karang taruna yang dapat berperan di Desa-desa sebagai pembangunan olahraga daerah yang dilaksanakan oleh organisasi karang taruna. 
Jika manajemen organisasi pertadingan olahraga diaplikasikan dalam lembaga social di masyarakat seperti Karang Taruna, maka dapat diartikan sebagai suatu proses pengelolaan organisasi social masyarakat secara efektif dan efisien untuk mencapai tujuan akan keberadaan Karang Taruna. Tujuan yang ingin dicapai tentu merupakan tujuan yang mendatangkan manfaat banyak orang dalam masyarakat terkait.

Dengan begitu manajemen system pertandingan olahraga yang disampaikan kepada karang taruna akan meningkatkan sumber daya manusia juga dapat diartikan sebagai ilmu yang mengatur manusia dalam suatu organisasi sebagai pondasi untuk mencapai tujuan. Tujuan utama manajemen system pertandingan olahraga pada karang taruna merupakan jalan untuk meningkatkan sumber daya manusia yaitu untuk memaksimalkan sumber daya olahraga dalam kontek ekonomi yang memiliki rasa dan karsa untuk menjalankan suatu organisasi social dalam wadah Karang Taruna. Dengan membangun manajemen sumberdaya manusia yang baik dalam organisasi dapat memudahkan pencapaian tujuan. Manaejmen diperlukan untuk daya guna, hasil guna organisasi dan unsur-unsur manajemen. Dapat digarisbawahi bahwa sumber daya manusia merupakan penggerak organisasi dan berfungsi secara aset yang harus dilatih dan dikembangkan kemampuannya dalam bidang system organisasi pertandingan, yang sering dilaksanakan kegiatan olahraga oleh karang taruna dalam membangun daerahnya melalui kualitas olahraga yang berkesinambungan untuk meningkatkan sport industry di desadesanya.

Pengembangan system pertandingan olahraga merupakan suatu cara efektif untuk menghadapi beberapa tantangan yang dihadapi di Desa Girimukti Kecamatan saguling Kab. Bandung Barat. Bagaimana Karang Taruna mampu mengatasi permasalahan tentang kegiatan olahraga yang menjadi proitas kegiatan kompetisi olahraga sehingga system pertandingan perlu dikuasai oleh pemuda Karang Taruna Desa Giri Mukti Kecamatan Saguling Kab. Bandung Barat ini dijadikan kemampuan mengatasi tantangan merupakan factor yang mempengaruhi keberhasilan organisasi karang Taruna dalam mempertahankan eksistensinya. Pengembangan sumber daya manusia melalui penguasaan Sistem Organisasi Pertandingan Olahraga bertujuan menghasilkan kerangka yang secara logis dan komprehensif mengembangkan organisasinya agar bermanfaat bagi organisasi dan masyarakat (Handoko, 2012).

Pengembangan sumber daya manusia juga sebagai upaya berkesinambungan meningkatkan mutu sumber daya manusia melalui pendidikan, pelatihan dan pembinaan (Sutrisno, 2014). Siapa yang perlu diberikan pendidikan, pelatihan dan pembinaan dalam organisasi social karang taruna? Tentu para remaja anggota karang taruna yang perlu di latih dan dibina gar mempunyai cukup bekal sebagai sumber daya manusia yang kompeten. Karena di pundak para remaja anggota karang taruna terdapat tanggungjawab yang besar sebagai generasi penerus pengisi kemerdekaan bangsa Indonesia. Generasi yang tangguh, terampil dan berakhlak mulia serta memiliki integritas yang tinggi merupakan dambaan semua kalangan. Berangkat dari krisis multidimensional yang dialami oleh bangsa ini 
sudah sepatutnya mempersiapkan generasi tersebut sebagai penerus dari estafet kepemimpinan di negeri ini. Akibat dari krisis moral ini banyak generasi muda mengalami nasib kurang beruntung, putus sekolah, terkena kasus narkoba, dan masih banyak kasus kriminal lainnya. Oleh karena itu, program pengembangan hendaknya dilakukan secara berkesinambungan dan berpedoman kepada keterampilan yang dibutuhkan organisasi untuk masa yang akan datang. Pengembangan harus bertujuan untuk meningkatkan kemampuan teknis, teoritis, konseptual, dan moral supaya produktivitas.

\section{METODE PELAKSANAAN KEGIATAN}

Dalam kegiatan ini metode yang diterapkan diharapkan dapat memberikan kemudahan kepada para pemuda yang tergabung dalam karang taruna Desa Girimukti Kecamatan Saguling Kabupaten Bandung Barat. Metode yang digunakan adalah metode diskusi kelompok, sharing, tanyajawab, praktik yang di damping oleh pemateri. Pada metode penjelasan, setiap instruktur menyampaikan materi terkait dan membuat tampilan visual berupa slide power point yang ditampilkan ke layar dengan LCD proyektor.

Instruktur dalam menyampaikan penjelasan juga memasukkan unsur "sharing" atau berbagi pengalaman mengenai pengelolaan system pertandingan Olahraga yang dilakukan oleh para pemuda karang taruna dan materi yang telah dimiliki pemateri, dengan pertimbangan tersebut diharapkan dapat memberikan gambaran lebih jelas kepada peserta. Pada metode praktik, peserta berkelompok dan dengan pendampingan panitia bergantian menyusun perencanaan system organisasi pertandingan olahraga secara bergantian berkaitan dengan temannya. Peserta diajarkan bagaiman acara menyusun daftar kebutuhan dan mereka diperbolehkan memberikan penambahan daftar keinginan yang ingin mereka capai beserta strategi untuk mencapainya. Dengan demikian karang taruna Desa Girimukti Kecamatan Saguling Kabupaten Bandung Barat tidak hanya sekedar terarah, dengan menggunakan pengelolaan Suatu Kompetisi Olahraga tetapi diberikan teknik pengundian dan pembagian group baik itu system pertandingan dengan system gugur, maupun system setengah kompetisi.

\section{HASIL DAN PEMBAHASAN}

Manajemen Sistem Pertandingan Olahraga dalam meningkatkan sumber daya manusia karang Taruna Desa Giri Mukti Kecamatan Saguling merupakan salah satu kebutuhan pemuda karang taruna dalam mengelola kompetisi kegiatan olahraga di Desa tersebut, menuju suatu kegiatan olahraga yang terarah dan menjadikan kompetisi yang berkualitas dilihat dari manajemen pertandingannya maupun arah prestasi olahraga di desa tersebut. Peningkatan Manajemen Peningkatan sumber daya manusia tidak semata-mata disajikan dalam kurikulum di Perguruan Tinggi saja tetapi bisa disisipkan pada para pemuda Karang Taruna yang merupakan tonggak untuk membangun prestasi olahraga di daerahnya. Sebenarnya pendidikan yang paling efektif dan efisien adalah pendidikan yang dimulai dari pendidikan keluarga, organisasi kepemudaan selain lingkungan pertama kali yang dikenal anak 
adalah lingkungan keluarga, waktu yang paling banyak juga dihabiskan di keluarga, sehingga karakter yang terbentuk lebih dominan dari pendidikan keluarga. Manajemen Sistem Pertandingan Olahraga pada Karang Taruna merupakan peningkatan sumber daya manusia di lingkungan keluarga dan Organisasi kepemudaan dapat dimulai dengan pemuda diberikan pendidikan diberi kesempatan untuk bersosialisasi, mengerjakan tugas secara berkelompok atau diberi tanggung jawab sesuai dengan tingkatan usianya. Perlu dibiasakan dari lingkungan organisasi kepemudaan yaitu Karang Taruna agar pemuda tumbuh menjadi pribadi yang berkarakter dan berkualitas dalam mengembangkan prestasi olahraga di daerahnya. Dengan memberikan kesempatan pada pemuda karang taruna untuk memanajemen atau mengelolaan system pertandingan olahraga secara otomatis akan merasa diberi kepercayaan dan tanggung jawab pada pemuda karang taruna. Pemuda akan dapat mengambil keputusan yang baik untuk dirinya sendiri, meskipun tetap dalam pengawasan orang-orang yang berpengalaman dalam berorganisasi. Begitu pemuda yang ada dikarang taruna tersebut sudah mempunyai dasar sebagai sumber daya manusia dalam system pertandingan olahraga secara manajemen bisa dikatakan layak untuk membangun daerahnya melalui kegiatan olahraga yang berkualitas dan dapat berintegritas. Kebiasaan yang positif harus terus dilakukan dan dikembangkan pada anak-anak muda, sehingga tumbuh kembang mereka terarah menjadi bibit-bibit sumber daya manusia dalam bidang olahraga terutama dalam manajemen pertandingan olahraga yang berkualitas.

Pentingnya manajemen system pertandingan olahraga ini merupakan sumber daya manusia dalam kehidupan kegiatan berolahraga menjadi tolak ukur perilakunya dalam bermasyarakat. Kebiasaan berorganisasi dalam kepemudaan juga dapat dicerminkan dalam Interaksinya dengan sesama manusia di lingkungan social. Oleh sebab itu kebiasaan yang baik dapat ditumbuh kembangkan pada lingkungan yang lebih luas dalam hal ini di organisasi social masyarakat seperti halnya karang taruna. Karang Taruna yang merupakan wadah remaja dan dewasa untuk mengembangkan kreativitas dan produktivitas. Mulai dari kalangan remajanya perlu ditumbuhkan bagaimana membangun sumber daya manusia dalam system pertandingan olahraga yang benar dan berkuawalitas akan membuat manusia itu tangguh dan tanggung jawab. Pendidikan andragogi yang merupakan pendidikan bagi orang dewasa, perlu membiasakan mendidik putra putrinya mengelola dirinya dengan baik, dan cara diberi kesempatan untuk mandiri, disiplin, tanggung jawab dan berani mengambil resiko.

Untuk itu tim pengusul pengabdian kepada masyarakat dari dosen Sekolah Tinggi Keguruan dan Ilmu Pendidikan (STKIP) Pasundan hadir ditengah-tengah masyarakat untuk berbagi pengetahuan tentang manajemen Sistem Pertandingan Olahraga untuk dapat meningkatkan sumber daya manusia agar masyarakat memiliki nilai lebih, karena manusia memang terlahir lebih bermartabat dibanding makhluk lain, sudah seyogyanya manusia harus lebih unggul dan bermartabat. Akal dan pikiran yang dianugerah sejak dilahirkan digunakan sebagai modal dasar mengembangkan diri sebagai manusia. Meskipun para remaja sudah mendapat wadah dan tergabung dalam organisasi social yaitu Karang Taruna bukan berarti 
terlepas tanggung jawab kita untuk memberikan perhatian, dukungan, motivasi, keterampilan dan pengetahuan. Justru pada usia remaja yang masih tergolong labil harus ditanamkan nilai-nilai kepribadian yang baik, agar tumbuh menjadi insan yang baik juga. Dari survey awal tim pengusul melihat gejala krisis moral yang melanda masyarakat Indonesia, terutama di kota-kota besar. Arus globalisasi tidak bisa dicegah, mau tidak mau, suka tidak suka sudah terjadi, jadi tinggal bagaimana kita menyikapi arus globalisasi tersebut. Arus globalisasi akan menjadi kekuatan yang luar biasa jika dimanfaatkan dengan baik dan benar, tetapi sebaliknya akan menjadi mala petaka jika tidak dimanfaatkan dengan baik. Maka dari itu sudah menjadi kewajiban kita untuk mengkondisikan remaja kita dalam kegiatan yang positif dan bermanfaat

\section{KESIMPULAN DAN SARAN}

Hasil kegiatan ini di harapkan para remaja tergerak untuk ikut membangun desa melalui kegiatan olahraga yang terarah baik secara manajemenya maupun secara prestasinya sehingga sebagai generasi penerus bangsa tersebut melalui kemasan kegiatan penyuluhan "manajemen sitem pertandingan olahraga dalam meningkatkan sumber daya manusia untuk pengembangan manajemen pengeloaan kompetisi olahraga di Desanya, dengan tujuan dapat mengembangkan peran karang taruna sebagaimana fungsinya.

Obyek pada kegiatan pengabdian kepada masyarakat ini adalah Karang Taruna yang anggotanya terdiri dari para remaja di wilayah Kampung Jalupang Desa Girimukti Kecamatan Saguling Kabupaten Bandung Barat karena tim pengusul melihat masih butuh pembinaan dalam mengelola sumber daya manusia nya agar lebih greget dan sungguh-sungguh, penuh tanggung jawab dalam menjalankan fungsi dan perannya pada masyarakat setempat, sehingga dapat memajukan Kampung Jalupang Khususnya Umumnya Desa Girimukti Kecamatan Saguling Kabupaten Bandung Barat.

\section{DAFTAR PUSTAKA}

Ajimat, A., Sunarsi, D., \& Sidiq, F. (2020). Berwirausaha Memanfaatkan Media Sosial Pada Daerah Sepatan. ADI Pengabdian Kepada Masyarakat, 1(1), 69-76.

Akhmad Sobarna, Sumbara Hambali, Sutiswo, Denok Sunarsi. (2020). The Influence learning used ABC run exercise on the sprint capabilities. Jurnal Konseling dan Pendidikan, 8 (2), 67-71.

Gita Febria Friskawati, Akhmad Sobarna, Mesa Rahmi Stephani. (2020), Teacherts' Perceptions of Physical Education Teaching Barriers at Elementary School, Konfrensi 4th International Conference on Sport Science, Health, and Physical Education (ICSSHPE 2019), 2 (19), 355-357. Handoko, Hani. 2012. Manajemen Personalia dan Sumber Daya Manusia Edisi 2. BPFE Yogyakarta. 
M. Ishaq. (2012). Pembinaan Nasionalisme Pemuda Pembatasan Melalui Program Pendidikan Luar Sekolah, Jurnal Ilmu Pendidikan, 6 (17), 459-468 Muchamad Ishak. (2015). Organisasi dan system pertandingan, Refika Aditama, $1(1), 12-15$.

Pranoto, P., Jasmani, J., \& Marayasa, I. N. (2019). Pelatihan Digital Marketing Untuk Peningkatan Perekonomian Anggota Karang Taruna Al Barkah Di Kampung Cicayur-Tangerang. Jurnal Pengabdian Dharma Laksana, 1(2), 250-258.

Sobarna, A., Rizal, R. M., Hambali, S., \& Sunarsi, D. (2020). Influence Make a Match Model toward Communication skills in Physical and Health Pedagogical Concept. Solid State Technology, 63(6), 1355-1363.

Sobarna, A., Sunarsi, D., \& Roinadi, D. K. (2020). The Effect of Pedagogic Competence Kids Athletic toward Motivation for Elementary School. Solid State Technology, 63(6),

Sunarsi, D. (2018). Buku Ajar: Seminar Perencanaan Sumber Daya Manusia. Tangerang Selatan: Asmoro Mediatama

Sunarsi, D., Kustini, E., Lutfi, A. M., Fauzi, R. D., \& Noryani, N. (2019). Penyuluhan Wirausaha Home Industry Untuk Meningkatkan Ekonomi Keluarga Dengan Daur Ulang Barang Bekas. Baktimas: Jurnal Pengabdian pada Masyarakat, 1(4), 188-193.

Sutrisno, S., \& Sunarsi, D. (2019). The Effect of Work Motivation and Discipline on Employee Productivity at PT. Anugerah Agung in Jakarta. Jurnal Ad'ministrare, 6(2), 187-196. 


\section{PANDUAN SINGKAT BAGI PENULIS JURNAL DHARMA LAKSANA}

Panduan penulisan ini dimaksudkan untuk menyeragamkan bentuk penulisan karya ilmiah yang dikirim penulis ke redaksi Jurnal Jenius, dengan panduan penulisan sebagai berikut :

1. Naskah ditulis dalam Bahasa Indonesia dengan Abstrak Bahasa Indonesia atau Bahasa Inggris dalam bentuk Font 12" dengan ukuran 1 Spasi dengan intisari tidak lebih dari 250 kata disertai 3 atau 4 kata kunci (keyword).

Naskah berupa Softcopy program MS maksimal 10 Halaman termasuk tabel dan gambar, spasi 1.

2. Sistematika penulisan disusun dengan urutan sebagai berikut :

a) Judul, nama dan alamat email penulis/peneliti tunggal.

b) Abstrak dan intisari, keyword dan kata kunci.

c) Batang Tubuh :

1). Pendahuluan, termasuk didalamnya intisari permasalahan

2). Metode Penelitian

3). Hasil dan Pembahasan

4). Kesimpulan dan Saran

5) Daftar Pustaka atau Referensi

6) Seluruh isi tersebut di buat dengan 1 kolom

3. Judul ditulis dalam bentuk font Times New Roman 12" dengan huruf besar kecil dicetak tebal dan ditempatkan ditengah halaman,, serta tidak lebih dari 18 kata.

4. Tulisan karya ilmiah dalam bentuk font Times New Roman 12" dengan ukuran spasi 1,0 spasi dalam bentuk kolom.

5. Gambar diberi nomor dan keterangan, sedangkan tabel diberi nomor dan keterangan diatasnya.

6. Penulisan persamaan matematika yang terdapat pada halaman naskah hendaknya menggunakan equation editor.

7. Daftar pustaka hanya memuat literature yang dirujuk dalam keterangan dan dicantumkan pada bagian akhir naskah dilakukan dengan memberikan nomor.

8. Margin atas dan kiri $4 \mathrm{~cm}$, kanan dan bawah $3 \mathrm{~cm}$, dan ukuran kertas A4.

9. Dokumentasi Foto kegiatan maksimal 5.

10. Email Redaksi : jpdl@unpam.ac.id /denoksunarsi@unpam.ac.id. 